\title{
Akademisi dalam Mencegah Peredaran Narkotika di Masyarakat (Sosialisasi Desa Bandar Baru Kecamatan Sibolangit Kabupaten Deli Serdang Provinsi Sumatera Utara)
}

\section{The Role of Academics in Preventing Narcotics Circulation in the Community (Socialization of Bandar Baru Village, Sibolangit District, Deli Serdang Regency, North Sumatra Province)}

\author{
M. Faisal Rahendra Lubis \\ Fakultas Hukum, Universitas Islam Sumatera Utara, Indonesia
}

Diterima: 13 Maret 2020; Disetujui: 20 Maret 2020; Dipublish: 24 Maret 2020

*Coresponding Email: rahendra_rif@yahoo.co.id

\begin{abstract}
Abstrak
Tujuan penelitian ini adalah untuk menganalisis peran akademisi dalam Pencegahan, penanggulangan penyalahgunaan, dan peredaran gelap narkoba. Harapannya, dapat terwujud stabilitas pembangunan nasional, masyarakat adil, makmur, dan sejahtera. Banyak upaya pemulihan namun keberhasilannya sendiri sangat bergantung pada sikap profesionalisme lembaga yang menangani program rehabilitasi ini, kesadaran dan kesungguhan penderita untuk sembuh serta dukungan kerja sama antara penderita, keluarga dan lembaga. Masalah yang paling sering timbul dan sulit sekali untuk dihilangkan adalah mencegah datangnya kembali kambuh (relaps) setelah penderita menjalani pengobatan. Untuk itu para aktivis di lingkungan kampus, diharapkan lebih meningkatkan perannya dalam memerangi penyalahgunaan narkoba melalui kegiatan dan aktivitas Anti-Narkoba baik pada tataran ilmiah maupun pada tataran praktik di lapangan, membentuk kelompok-kelompok pendidik sebaya yang bertugas membantu mensosialisasikan bahaya penyalahgunaan narkoba dan mendorong terbentuknya aktifitas dalam kampus, seperti halnya pengembangan pusat informasi dan konseling masalah penyalahgunaan narkoba
\end{abstract}

Kata Kunci: Akademisi, Mencegah, Peredaran Narkotika

\begin{abstract}
The purpose of this study is to analyze the role of academics in the prevention, prevention of abuse, and illicit drug trafficking. It is hoped that national development stability, a just, prosperous and prosperous society can be realized. Many recovery efforts, but the success itself is very dependent on the attitude of professionalism of institutions that handle this rehabilitation program, awareness and sincerity of patients to recover as well as support for cooperation between patients, families and institutions. The problem that most often arises and is very difficult to eliminate is to prevent relapses after patients undergo treatment. For this reason activists in the campus environment are expected to further enhance their role in combating drug abuse through Anti-Narcotics activities and activities both at the scientific level and at the practice level in the field, forming peer educator groups whose task is to help socialize the dangers of drug abuse and encourage the formation of activities on campus, such as the development of information centers and counseling on drug abuse issues
\end{abstract}

Keywords: Academics, Preventing, Narcotics Circulation

How to Cite: Lubis, M.F.R. (2020). Peran Akademisi Dalam Mencegah Peredaran Narkotika Di Masyarakat (Sosialisasi Desa Bandar Baru Kecamatan Sibolangit Kabupaten Deli Serdang Provinsi Sumatera Utara). Journal of Education, Humaniora, and Social Sciences (JEHSS), 2 (3): 658-672. 


\section{PENDAHULUAN}

Penyalahgunaan Narkotika, Psikotropika, dan Zat Adiktif lainnya di Indonesia sekarang ini semakin mengkhawatirkan, hal ini disebabkan oleh banyak faktor diantaranya letak geografis Indonesia yang berada diantara dua benua dan memiliki 17.504 pulau yang terbentang dari sabang sampai merauke menyebabkan kurannya pengawasan, serta banyaknya sungai-sungai yang bermuara ke laut yang cukup ideal dijadikan sebagai jalur tikus peredaran barang gelap narkotika.

Pengertian narkotika berdasarkan Pasal 1 angka 1 Undang-Undang Republik Indonesia Nomor 35 Tahun 2009 tentang Narkotika, Narkotika adalah zat atau obat yang berasal dari tanaman atau bukan tanaman, baik sintetis maupun semisintesis, yang dapat menyebabkan penurunan atau perubahan kesadaran, hilangnya rasa, mengurangi sampai menghilangkan rasa nyeri, dan dapat menimbulkan ketergantungan yang dibedakan ke dalam golongan-golongan sebagaimana terlampir dalam Undang-Undang. Untuk melakukan pencegahan dan dan penyediaan narkotika demi kepentingan pengobatan dan pelayanan kesehatan, maka salah satu upaya pemerintah ialah dengan melakukan pengaturan secara hukum tentang pengedaran, impor, ekspor, menanam penggunaan narkotika secara terkendali dan dilakukan pengawasan yang ketat.

Pasal 4 Huruf (a) Undang-Undang Republik Indonesia Nomor 35 Tahun 2009 Tentang Narkotika menyatakan bahwa menjamin kesediaan narkotika untuk kepentingan pelayan kesehatan dan/atau pengembangan ilmu pengetahuan dan dapat digunakan untuk kepentingan pelayanan kesehatan dan/atau pengembangan ilmu pengetahuan dan teknologi. Akan tetapi, pada prakteknyadidalam lingkungan banyak sekali terjadi penyalahgunaan terhadap narkotika.

Korban penyalahgunaan narkoba sudah merebak keseluruh lapisan masyarakat tidak terkecuali generasi muda, generasi yang diharapkan sebagai penerus bangsa di masa yang akan datang. Hal ini disebabkan banyak faktor diantaranya akibat keluarga bermasalah (broken home), pergaulan bebas, dan lain-lain.

Penyalahgunaan narkoba di Provinsi Sumatera Utara dalam tingkat yang mengkhawatirkan Badan Nasional Narkotika Provinsi Sumatera Utara (BNNP Sumut) mencatat sebanyak 256.000 masyarakat di Sumatera Utara terpapar oleh narkoba.130.000 diantaranya merupakan kalangan remaja (1https://regional.kompas.com/read/2019/05/21/17140411/bnn-sebut-256000- 
warga-sumatera-utara-terpapar-narkoba?page=all.Diakses pada tanggal 15 Januari 2020, Pukul 15.00 Wib.)

Badan Narkotika Nasional dan Polri sebagai aparat penegak hukum telah diberikan kewenangan yang besar oleh undang-undang dalam upaya pencegahan dan penindakan bagi setiap orang yang menyalahgunakan narkotika (Silalahi, 2018; Hutagaol, 2019). Akan tetapi hal ini belum efektif dalam mengurangi tingginya angka penyalahgunaan narkoba di tengah-tengah masyarakat karena masih banyak oknum-oknum aparat penegak hukum yang bermain mata dengan para bandar, bahkan tidak jarang membekabdan meloloskan peredaran barang gelap narkotika (Nainggolan, Zahara \& Saparuddin, 2010; Sirait \& Rafiqi, 2018).

Untuk itu perlu dilakukan cara-cara pencegahan melalui metode pendekatan promotif dan preventif, dimana masyarakat harus diberdayakan melalui pemberian peranan dan kegiatan agar masyarakat jauh dari pengaruh jerat narkoba yang merugikan banyak pihak, serta perlu diadakan penguatan karakter dan peningkatan moral dikalangan generasi muda. Maka daripada itu peran akademisi (dosen) dalam upaya pencegahan peredaran narkotika ditengah-tengah masyarakat menjadi sangat penting mengingat tugas dosen sebagai pendidik untuk menyebarkan ilmu pengetahuan yang salah satunya melalui pengabdian kepada masyarakat.

Menurut Pasal 1 Angka 2 Undang-Undang Nomor 14 Tahun 2005 Tentang Guru Dan Dosen yang dimaksud dengan Dosen adalah pendidik profesional dan ilmuwan dengan tugas utama mentransformasikan, mengembangkan, dan menyebarluaskan ilmu pengetahuan, teknologi, dan seni melalui pendidikan, penelitian, dan pengabdian kepada masyarakat.

Desa Bandar Baru merupakan salah satu desa di Kecamatan Sibolangit Kabupaten Deli Serdang Provinsi Sumatera Utara. Desa Bandar Baru memiliki Jumlah penduduk sebanyak 4.523 jiwa. Yaitu terdiri dari 2.457 jiwa penduduk laki-laki dan 2.166 jiwa penduduk perempuan.

Desa Bandar Baru memiliki luas 1250 Ha atau sekitar 22,26 km persegi. Dengan batas-batas sebagai berikut: Sebelah Utaraberbatasandengan Desa Suka Makmur; Sebelah Selatan berbatasan dengan berbatasan dengan Kabupaten Dati II Karo; Sebelah Timur berbatasan dengan berbatasan dengan Sei Betimus/ Desa Durin Sirugun; Sebelah Baratberbatasandenganberbatasan dengan Desa Sikeben. 
Total luas tersebut meliputi kawasan Taman Wisata Sibolangit, kawasan pemukiman, terminal, pasar, sarana rekreasi, penginapan-penginapan, dan lahan pertanian. Desa Bandar Baru berada pada ketinggian $860 \mathrm{M}$ diatas permukaan air laut. Suhu rata-ratanya berkisar $18^{\circ} \mathrm{C}-26^{\circ} \mathrm{C}$ dengan kelembaban udara yang relatif tinggi, topografi desa ini terletak di dataran tinggi dengan curah hujan sepanjang tahun berkisa antara $3250 \mathrm{Mm} /$ tahun. Keadaan ini menyebabkan suasana sejuk di kawasan ini.

Selain sebagai tempat rekreasi Desa Bandar Baru seringkali dijadikan sebagai tempat persinggahan oleh wisatawan dari Medan yang ingin berkunjung ke Brastagi dan sebaliknya, hal ini dibuktikan dengan banyaknya penginapan, hotel, rumah makan dan pusat oleh-oleh sepanjang jalan di Desa Bandar Baru, mengingat letaknya yang berada ditengah-tengah Kota Medan dan Kabupaten Tanah Karo.

Banyaknya wisatawan yang berkunjung maupun sekedar singgah sering kali dimanfaatkan oleh para pengedar untuk menjajakan barang haram narkoba kepada para pengunjung, belum lagi ditambah dengan banyaknya tempat-tempat yang diduga dijadikan sebagai tempat prostitusi.

Berdasarkan realitas yang demikian, maka perlu dilakukan Penelitian mengenai "Peran Akademisi dalam Mencegah Peredaran Narkotika di Masyarakat (Sosialisasi Desa Bandar Baru Kecamatan Sibolangit Kabupaten Deli Serdang Provinsi Sumatera Utara).”

\section{METODE PENELITIAN}

Dalam penelitian ini metode penelitian yang digunakan adalah metode penelitian kuantitatif. Metode penelitian kuantitatif merupakan salah satu jenis penelitian yang spesifikasinya adalah sistematis, terencana, dan terstruktur. Menurut Sugiyono (2012), metode penelitian kuantitatif dapat diartikan sebagai metode penelitian yang berlandaskan peda filsafat positivisme, digunakan untuk meneliti pada populasi atau sampel tertentu. Teknik pengambilan sampel pada umumnya dilakukan secara random, pengumpulan data mengunakan instrument penelitian, analisis data bersifat kuantitatif atau statistik dengan tujuan untuk menguji hipotesa yang telahditetapkan.

Fokus penelitan perlu ditetapkan guna membatasi studi dan berfungsi pula untuk memenuhi kriteria inklusi-eklusi atau memasukan-mengeluarkan suatu informasi baru yang diperoleh di lapangan. Secara sederhana fokus penelitian adalah fenomena yang menjadi pusat penelitian dari seorang peneliti. 
Penelitan ini difokuskan pada: Intensitas penyalahgunaan narkoba; 2. Tekanan ekonomi yang diakibatkan pelahgunaan narkoba; Kriminalitas sebagai bentuk akibat dari penyalahgunaan narkoba; Hubungan sebab akibat intensitas penyalahgunaan narkoba dengan tingkat kriminalitas

Data yang dipergunakan dalam penelitian ini adalah data sekunder yang berupa literatur hukum, undang-undang, putusan pengadilan, makalah dan atau artikel yang termuat di media cetak maupun elektronik. Data sekunder yang dipergunakan dalam penelitian ini terdiri dari bahan hukum primer yang bersifat otoritatif yang artinya mempunyai otoritas, bahan hukum sekunder dan bahan hukum tertier.

Bahan hukum primer yang bersifat otoritatif yang dipergunakan dalam penelitian ini terdiri dari: Undang-Undang Dasar Republik Indonesia Tahun 1945; Kitab Undangundang Hukum Pidana; Kitab Undang-undang Hukum Perdata.

Bahan hukum sekunder yang dipergunakan dalam penelitian ini adalah doktrin hukum yang termuat di dalam buku literatur hukum perdata dan pidana, artikel dalam jurnal hukum, atau makalah yang ditulis para ahli yang materinya relevan dengan penelitian ini. Sedangkan bahan hukum tertier yang dipergunakan dalam penelitian ini adalah kamus hukum, ensiklopedia hukum dan kamus bahasa Indonesia.

Data sekunder untuk penelitian ini diperoleh melalui kepustakaan atau studi kepustakaan meliputi Buku-buku hukum, Undang-undang, Putusan Pengadilan, dan lainlain baik yang termuat pada media cetak maupun media elektronik.

Dalam upaya memperoleh data yang akurat, dalam penelitian ini data diperoleh dengan menggunakan alat pengumpulan data menelaah dan menginventarisasi bahanbahan hukum di kepustakaan (Library Research). Yaitu pengumpulan data dengan mengadakan studi telaah terhadap buku, literatur, Undang-Undang yang mempunyai korelasi dengan masalah yang diteliti

Analisis data dalam penelitian ini dilakukan analisis kualitatif. Data yang telah dihimpun dan diklasifikasi sesuai dengan permasalahan penelitian ini kemudian dilakukan analisis secara kualitatif (content analysis) dengan melakukan penafsiran atas data yang ada.

Hasil analisis kualitatif atau penafsirkan data kemudian diambil maknanya sehingga diketahui inti dari isi norma hukum yang diteliti dan dari makna tersebut digunakan untuk menjawab permasalahan yang ada sehingga diperoleh kesimpulan dari penelitian ini. 


\section{HASIL DAN PEMBAHASAN}

\section{Peran Akademisi Dalam Melaksanakan Tugasnya}

Kondisi bangsa Indonesia saat ini, permasalahan narkoba yang sudah masuk ke dalam kondisi darurat, dimana tingkat penyalahgunaanya sudah sangat meresahkan berbagai pihak. Oleh sebab itu kita harus lebih berhati-hati dan berupaya semaksimal mungkin untuk menekan penyalahgunaan narkoba yang suatu saat dapat mengancam lingkungan kita. Menanggulangi masalah narkoba bisa dimulai dari lingkungan keluarga, lingkungan masyarakat, serta lingkungan kerja baik pemerintah dan swasta secara bersama-sama menginformasikan tentang narkoba dan permasalahannya dengan harapan memiliki pemahaman, kesadaran dan memilki sikap menolak penyalahgunaan dan peredaran gelap narkoba

Merespon perkembangan permasalahan narkoba yang terus meningkat dan makin serius, maka Ketetapan MPR-RI Nomor VI/MPR/2002 melalui Sidang Umum Majelis Permusyawaratan Rakyat Republik Indonesia (MPR-RI) Tahun 2002 telah merekomendasikan kepada DPR-RI dan Presiden RI untuk melakukan perubahan atas Undang-Undang Nomor 22 Tahun 1997 tentang Narkotika. Oleh karena itu,

Pemerintah dan DPR-RI mengesahkan dan mengundangkan Undang-Undang Nomor 35 Tahun 2009 tentang Narkotika, sebagai perubahan atas UU Nomor 22 Tahun 1997. Berdasarkan UU Nomor 35 Tahun 2009 tersebut, Badan Narkotika Nasional (BNN) diberikan kewenangan penyelidikan dan penyidikan tindak pidana narkotika dan prekursor narkotika.

Merespon perkembangan permasalahan narkoba yang terus meningkat dan makin serius, maka Ketetapan MPR-RI Nomor VI/MPR/2002 melalui Sidang Umum Majelis Permusyawaratan Rakyat Republik Indonesia (MPR-RI) Tahun 2002 telah merekomendasikan kepada DPR-RI dan Presiden RI untuk melakukan perubahan atas Undang-Undang Nomor 22 Tahun 1997 tentang Narkotika.

Pemerintah dan DPR-RI mengesahkan dan mengundangkan Undang-Undang Nomor 35 Tahun 2009 tentang Narkotika, sebagai perubahan atas UU Nomor 22 Tahun 1997. Oleh karena itu, Pemerintah dan DPR-RI mengesahkan dan mengundangkan UndangUndang Nomor 35 Tahun 2009 tentang Narkotika, sebagai perubahan atas UU Nomor 22 Tahun 1997. Berdasarkan UU Nomor 35 Tahun 2009 tersebut, Badan Narkotika Nasional (BNN) diberikan kewenangan penyelidikan dan penyidikan tindak pidana narkotika dan 


\section{Peran Akademisi Dalam Mencegah Peredaran Narkotika Di Masyarakat Desa Bandar Baru Kecamatan Sibolangit Kabupaten Deli Serdang Provinsi Sumatera Utara}

Garis intelektual mahasiswa merupakan komponen bangsa yang sarat nilai sosiokultural, sehingga dapat dipecaya karena dikenal memiliki idealisme tinggi. Mahasiswa telah terbukti mampu mendobrak aneka ketimpangan sosial di dalam masyarakat. Untuk itu para aktivis di lingkungan kampus, diharapkan lebih meningkatkan perannya dalam memerangi penyalahgunaan narkoba melalui kegiatan dan aktivitas AntiNarkoba baik pada tataran ilmiah maupun pada tataran praktik di lapangan, membentuk kelompok-kelompok pendidik sebaya yang bertugas membantu mensosialisasikan bahaya penyalahgunaan narkoba dan mendorong terbentuknya aktifitas dalam kampus, seperti halnya pengembangan pusat informasi dan konseling masalah penyalahgunaan narkoba (Priyambodo, 2002).

Semua itu diupayakan dalam rangka menyelamatkan generasi bangsa Indonesia dari ancaman kehancuran akibat narkoba.18 Peran serta mahasiswa sangatlah besar dan harus digerakkan secara maksimal dalam menanggulangi peredaran dan penyalahgunaan narkoba di penjuru negeri. Di antara dengan aksi nyata dengan kegiatan yang dilakukan dapat secara pre-emtif, dan preventif yaitu (Nitibaskara, 2001):

1. Mahasiswa di tempat tinggalnya masing-masing membentuk kelompok antinarkoba di setiap RT

2. Mahasiswa bisa mendorong setiap warga di RT lain untuk membentuk dan menggalang kelompok anti-narkoba

3. Mahasiswa bersama ketua RT mengadakan sambang rumah, tiap-tiap rumah di datangi untuk mensosialisasikan bahaya narkoba

4. Mahasiswa bersama warga harus bergerak di setiap rumah untuk menemukan korban pengguna narkoba dan pengedar narkoba

5. Mahasiswa bisa membawa korban pengguna narkoba ditempat rehabilitasi narkoba untuk di rawat dengan baik

6. Mahasiswa bisa menyerahkan para pengedar dan bandar narkoba ke Polisi setempat.

7. Penting sekali menumbuhkan kesadaran akan bahayanya penyalahgunaan narkoba, sehingga paling sedikit dapat memproteksi diri dari pengaruh luar (ajakan teman).

8. Penting sedikit mengenal dan memahami apa itu narkoba, agar tahu mana sesuatu yang berbahaya sehingga memperkecil diperdaya orang. 
9. Menjadi yang terdepan dalam keluarga untuk menghindarkan anggota keluarga dari bahaya penyalahgunaan narkoba, jangan sebaliknya menjadi pelaku.

10. Menumbuhkan gagasan-gagasan dalam bentuk kegiatan positif (kreatif) yang dapat mengalihkan perhatian teman-teman sebaya untuk terpengruh oleh narkoba.

11. Dapat menjadi mitra aparat penegak hukum, setidaknya sebagai informasi terhadap indikasi penyalahgunaan narkoba.

12. Pengembangan pengetahuan kerohanian atau keagamaan

13. Pelaksanaan kampanye sosialisasi anti-narkoba

14. Pembinaan atau bimbingan dari partisipasi mahasiswa secara aktif untuk menghindari penyalahgunaan tersebut dengan mengisi kegiatan-kegiatan yang positif.

Perguruan Tinggi sebagai Lembaga Pendidikan jenjang terakhir dari hirarki pendidikan formal mempunyai tiga misi yang diemban yaitu Pendidikan, Penelitian, dan Pengabdian Masyarakat atau lebih dikenal dengan Tri Dharma Perguruan Tinggi. Tiga misi yang diembankannya tersebut bukanlah misi yang ringan untuk direalisasikan (Gosita, 2010). Misi Pendidikan di Perguruan Tinggi merupakan proses berlangsungnya pewarisan ilmu pengetahuan dari satu generasi ke generasi berikutnya, agar dengan demikian proses alih generasi juga diikuti dengan proses alih ilmu pengetahuan yang berorientasi pada tuntutan zaman, maka dalam proses berlangsungnya pewarisan ilmu pengetahuan membutuhkan pengembangan konsep atau teori ke arah konsep atau teori yang lebih baik. Usaha pengembangan teori atau konsep dilaksanakan secara sistematis dan melalui prosedur ilmiah, kegiatan ini disebut penelitian

Perlu diketahui, pencegahan, penanggulangan penyalahgunaan, dan peredaran gelap narkoba merupakan tanggung jawab bersama guna mewujudkan kamtibmas yang aman dan kondusif. Harapannya, dapat terwujud stabilitas pembangunan nasional, masyarakat adil, makmur, dan sejahtera.

Terdapat beberapa langkah yang dapat diperbuat. Pertama, selalu waspada dengan perkembangan teknologi, canggihnya teknologi membuat para pengedar dapat dengan mudah melancarkan niatnya untuk mengedarkan obat terlarang tersebut. Kedua, tanamkan keteladanan agar dapat memberi bimbingan dan dorongan untuk berbuat lebih baik. Ketiga adalah peduli, sekaligus hal paling penting untuk mencegah dan memberantas penyalahgunaan narkoba. Terdapat beberapa langkah yang dapat diperbuat. Pertama, selalu waspada dengan perkembangan teknologi, canggihnya teknologi membuat para 
pengedar dapat dengan mudah melancarkan niatnya untuk mengedarkan obat terlarang tersebut. Kedua, tanamkan keteladanan agar dapat memberi bimbingan dan dorongan untuk berbuat lebih baik. Ketiga adalah peduli, sekaligus hal paling penting untuk mencegah dan memberantas penyalahgunaan narkoba. Peredaran dan penyalahgunaan narkoba di Desa Bandar Baru Kecamatan Sibolangit Kabupaten Deli Serdang Provinsi Sumatera Utara: Sulitnya deteksi-deteksi tempat masuknya narkoba ke Desa Bandar Baru; Aparat yang masih sangat minim yang ditambah lagi dengan sarana dan prasarana yang tidak memadai, sebagian masyarakat masih enggan dan masih kurang peduli untuk melapor kepada aparat yang berwenang tentang peredaran/informasi narkoba; Sebagian masyarakat atau pihak orang tua/wali atau keluarga masih enggan untuk datang melapor tentang anaknya, keluarganya yang menyalahgunakan atau sebagai pecandu narkoba kepada aparat yang berwenang.

Untuk penanggulangan penyalahgunaan narkoba diperlukan upaya yang terpadu dan komprenhensif yang meliputi upaya preventif, represif, terapi dan rehabilitasi Penyebab terjadinya penyalahgunaan narkoba disebabkan oleh beberapa faktor yang saling mempengaruhi satu sama lain, yaitu: 1) Faktor letak geografi Indonesia; 2) Faktor ekonomi; 3) Faktor kemudahan memperoleh obat; 4) Faktor keluarga dan masyarakat; 5) Faktor kepribadian; 6) Faktor fisik dari individu yang menyalahgunakannya.

\section{Pencegahan Penyalahgunaan Narkoba}

Metode pencegahan dan pemberantasan penyalahgunaan narkoba yang paling efektif dan mendasar adalah metode promotif dan preventif. Upaya yang paling praktis dan nyata adalah represif dan upaya yang manusiawi adalah kuratif serta rehabilitatif.

Program promotif ini kerap disebut juga sebagai program preemtif atau program pembinaan. Pada program ini yang menjadi sasaran pembinaanya adalah para anggota masyarakat yang belum memakai atau bahkan belum mengenal narkoba sama sekali. Prinsip yang dijalani oleh program ini adalah dengan meningkatkan peranan dan kegitanan masyarakat agar kelompok ini menjadi lebih sejahtera secara nyata sehingga mereka sama sekali tidak akan pernah berpikir untuk memperoleh kebahagiaan dengan cara menggunakan narkoba. Bentuk program yang ditawrkan antara lain pelatihan, dialog interaktif dan lainnya pada kelompok belajar, kelompok olah raga, seni budaya, atau kelompok usaha. Pelaku program yang sebenarnya paling tepat adalah lembaga-lembaga masyarakat yang difasilitasi dan diawasi oleh pemerintah. 
Program preventif ini disebut juga sebagai program pencegahan dimana program ini ditujukan kepada masyarakat sehat yang sama sekali belum pernah mengenal narkoba agar mereka mengetahui tentang seluk beluk narkoba sehingga mereka menjadi tidak tertarik untuk menyalahgunakannya. Program ini selain dilakukan oleh pemerintah, juga sangat efektif apabila dibantu oleh sebuah instansi dan institusi lain termasuk lembagalembaga profesional terkait, lembaga swadaya masyarakat, perkumpulan, organisasi masyarakat dan lainnya. Bentuk dan agenda kegiatan dalam program preventif ini:

Program pemberian informasi satu arah dari pembicara kepada pendengar tentang bahaya penyalahgunaan narkoba. Kampanye ini hanya memberikan informasi saja kepada para pendengarnya, tanpa disertai sesi tanya jawab. Biasanya yang dipaparkan oleh pembicara hanyalah garis besarnya saja dan bersifat informasi umum. Informasi ini biasa disampaikan oleh para tokoh masyarakat. Kampanye ini juga dapat dilakukan melalui spanduk poster atau baliho. Pesan yang ingin disampaikan hanyalah sebatas arahan agar menjauhi penyalahgunan narkoba tanpa merinci lebih dala mengenai narkoba.

Penyuluhan seluk beluk narkoba Berbeda dengan kampanye yang hanya bersifat memberikan informasi, pada penyuluhan ini lebih bersifat dialog yang disertai dengan sesi tanya jawab. Bentuknya bisa berupa seminar atau ceramah. Tujuan penyuluhan ini adalah untuk mendalami pelbagai masalah tentang narkoba sehingga masyarakat menjadi lebih tahu karenanya dan menjadi tidak tertarik enggunakannya selepas mengikuti program ini. Materi dalam program ini biasa disampaikan oleh tenaga profesional seperti dokter, psikolog, polisi, ahli hukum ataupun sosiolog sesuai dengan tema penyuluhannya.

Perlu dilakukan pendidikan dan pelatihan didalam kelompok masyarakat agar upaya menanggulangi penyalahgunaan narkoba didalam masyarakat ini menjadi lebih efektif. Pada program ini pengenalan narkoba akan dibahas lebih mendalam yang nantinya akan disertai dengan simulasi penanggulangan, termasuk latihan pidato, latihan diskusi dan latihan menolong penderita. Program ini biasa dilakukan dilebaga pendidikan seperti sekolah atau kampus dan melibatkan narasumber dan pelatih yang bersifat tenaga profesional.

\section{Upaya mengawasi dan mengendalikan produksi dan upaya distribusi narkoba di masyarakat.}

Pada program ini sudah menjadi tugas bagi para aparat terkait seperti polisi, Departemen Kesehatan, Balai Pengawasan Obat dan Makanan (BPOM), Imigrasi, Bea 
Cukai, Kejaksaan, Pengadilan dan sebagainya. Tujuannya adalah agar narkoba dan bahan pembuatnya tidak beredar sembarangan didalam masyarakat namun melihat keterbatasan jumlah dan kemampuan petugas, program ini masih belum dapat berjalan optimal.

Kuratif, Program ini juga dikenal dengan program pengobatan dimana program ini ditujukan kepada para peakai narkoba.Tujuan dari program ini adalah mebantu mengobati ketergantungan dan menyembuhkan penyakit sebagai akibat dari pemakaian narkoba, sekaligus menghentikan peakaian narkoba.Tidak sembarang pihak dapat mengobati pemakai narkoba ini, hanya dokter yang telah mempelajari narkoba secara khususlah yang diperbolehkan mengobati dan menyembuhkan pemakai narkoba ini.Pngobatan ini sangat rumit dan dibutuhkan kesabaran dala menjalaninya.Kunci keberhasilan pengobatan ini adalah kerjasama yang baik antara dokter, pasien dan keluarganya.

Bentuk kegiatan yang yang dilakukan dalam program pengobat ini adalah: a) Penghentian secara langsung; b)Pengobatan gangguan kesehatan akibat dari penghentian dan pemakaian narkoba (detoksifikasi); c) Pengobatan terhadap kerusakan organ tubuh akibat pemakaian narkoba; d) Pengobatan terhadap penyakit lain yang dapat masuk bersama narkoba seperti HIV/AIDS, Hepatitis B/C, sifilis dan lainnya.

Pengobatan ini sangat kompleks dan memerlukan biaya yang sangat mahal. Selain itu tingkat kesembuhan dari pengobatan ini tidaklah besar karena keberhasilan penghentian penyalahgunaan narkoba ini tergantung ada jenis narkoba yang dipakai, kurun waktu yang dipakai sewaktu menggunakan narkoba, dosis yang dipakai, kesadaran penderita, sikap keluarga penderita dan hubungan penderita dengan sindikat pengedar.

Selain itu ancaman penyakit lainnya seperti HIV/AIDS juga ikut mempengaruhi, walaupun bias sembuh dari ketergantungan narkoba tapi apabila terjangkit penyakit seperti AIDS tentu juga tidak dapat dikatakan berhasil

Rehabilitatif, Program ini disebut juga sebagai upaya pemulihan kesehatan jiwa dan raga yang ditujukan kepada penderita narkoba yang telah lama menjalani program kuratif. Tujuannya agar ia tidak memakai dan bisa bebas dari penyakit yang ikut menggerogotinya karena bekas pemakaian narkoba. Kerusakan fisik, kerusakan mental dan penyakit bawaan macam HIV/AIDS biasanya ikut menghampiri para pemakai narkoba. Itulah sebabnya mengapa pengobatan narkoba tanpa program rehabilitasi tidaklah bermanfaat. 
Setelah sembuh masih banyak masalah yang harus dihadapi oleh bekas pemakai tersebut, yang terburuk adalah para penderita akan merasa putus asa setelah dirinya tahu telah terjangit penyakit macam HIV/AIDS dan lebih memilih untuk mengakhiri dirinya sendiri. Cara yang paling banyak dilakukan dalam upaya bunuh diri ini adalah dengan cara menyuntikkan dosis obat dalam jumlah berlebihan yang mengakibatkan pemakai mengalami Over Dosis (OD). Cara lain yang biasa digunakan untuk bunuh diri dalah dengan melompat dari ketinggian, membenturkan kepala ke tembok atau sengaja melempar dirinya untuk ditbrakkan pada kendaraaan yang sedang lewat. Banyak upaya pemulihan namun keberhasilannya sendiri sangat bergantung pada sikap profesionalisme lembaga yang menangani program rehabilitasi ini, kesadaran dan kesungguhan penderita untuk sembuh serta dukungan kerja sama antara penderita, keluarga dan lembaga.

Masalah yang paling sering timbul dan sulit sekali untuk dihilangkan adalah mencegah datangnya kembali kambuh (relaps) setelah penderita menjalani pengobatan. Relaps ini disebabkan oleh keinginan kuat akibat salah satu sifat narkoba yang bernama habitual.Cara yang paling efektif untuk menangani hal ini adalah dengan melakukan rehabilitasi secara mental dan fisik.Untuk pemakaipsikotropika biaanya tingkat keberhasilan setlah pengobatan terbilang sering berhasil, bahkan ada yang bisa sembuh 100 persen.

Represif, merupakan program yang ditujukan untuk menindak para produsen, bandar, pengedar dan pemakai narkoba secara hukum.Program ini merupakan instansi peerintah yang berkewajiban mengawasi dan mengendalikan produksi aupun distribusi narkoba.Selain itu juga berupa penindakan terhadap pemakai yang melanggar undangundang tentang narkoba

Masalah penyalahgunaan narkoba adalah masalah yang kompleks yang pada umumnya disebabkan oleh tiga faktor yaitu: faktor individu, faktor lingkungan/sosial dan faktor ketersediaan, menunjukkan bahwa pencegahan penyalahgunaan narkoba yang efektif memerlukan pendekatan secara terpadu dan komprehensif. Pendekatan apa pun yang dilakukan tanpa mempertimbangkan ketiga faktor tersebut akan mubazir. Oleh karena itu peranan semua sektor terkait termasuk para orangtua, guru, tokoh masyarakat, tokoh agama, kelompok remaja dan LSM di masyarakat, dalam pencegahan narkoba sangat penting. 
Dalam hal ini, mahasiswa haruslah menjadi pelopor sejati dalam memberantas narkoba, bukan hanya sebagai "penonton" bahkan menjadi pemilik, penadah, pengedar, atau pemakai. Selain menjadi salah satu mesin propaganda yang mampu merobohkan sebuah ketidakbenaran, mahasiswa diharapkan menjadi kelompok massa idealis yang menjunjung tinggi nilai-nilai norma serta moral, juga menjadi agen perubahan terutama di dunia pendidikan.

\section{Mengatasi Hambatan Akademisi Dalam Melakukan Upaya Pencegahan Peredaran Narkotika}

Tidak dapat dipungkiri bahwa kasus penyalahgunaan narkoba di Indonesia pun semakin bertambah dari tahun ke tahun, bukan hanya menyerang kaum muda saja tetapi juga golongan setengah baya maupun golongan usia tua.

Melihat kenyataan yang terjadi dan dampak negatifnya yang sangat besar dimasa yang akan datang, maka semua elemen bangsa ini, seperti pemerintah, aparat penegak hukum, institusi pendidikan, masyarakat dan lain sebagainya melakukan gerakan memerangi narkotika secara serius dan terus menerus, baik dengan pendekatan preventif maupun represif. ehingga upaya pencegahan dan penanggulangan narkotika ini dapat berjalan dengan efektif. lepas dari tujuannya untuk meniadakan keberadaan narkotika yang beredar bebas di lingkungan masyarakat yang dapat merusak masa depan bangsa utamanya pada kalangan remaja yang merupakan generasi penerus bangsa, untuk mewujudkan program badan narkotika nasional dalam memberantas peredaran narkotika maka badan narkotika nasional telah bekerjasama dengan berbagai instansi pemerintahan mauapun non pemerintahan dalam berbagai kegiatan yang telah dilaksanakan berkaitan dengan upaya program pencegahan.

Salah satu faktor pendukung upaya Pencegahan dan Pemberantasan Penyalahgunaan dan Peredaran Gelap Narkoba yaitu dengan adanya Instruksi Presiden No.12 Tahun 2011 serta kerjasama institusi pemerintah, swasta dan komponen masyarakat merupakan tanggungjawab Sub Bagian Perencanaan Bagian Umum. Alasan penetapan kerjasama institusi pemerintah, swasta dan komponen masyarakat dimasukkan dalam indicator keberhasilan kinerja

Ketersediaan SDM. Salah satu faktor pendukung upaya Pencegahan dan Pemberantasan Penyalahgunaan dan Peredaran Gelap Narkoba dapat berdayaguna dan 
berhasil guna bila kebutuhan sumberdaya dapat terpenuhi yang diharapkan dapat menurunkan angka prevalensi penyalahgunaan Narkoba, wawancara yang peneliti lakukan maka diketahui bahwa dalam ketersediaan

SDM di Desa Bandar Baru Kecamatan Sibolangit Kabupaten Deli Serdang Provinsi Sumatera Utara masih kekurangan tenaga kerja khususnya pada bidang rehabilitasi sehingga terjadi kendala dalam melakukan proses rehabilitasi kepada para pengguna. Anggaran. Sebagai salah satu faktor penghambat karena program pemberantasan peredaran narkotika di Desa Bandar Baru membutuhkan anggaran yang cukup besar dalam pengadaan program pemberantasan. Akibat kekurangan dana tersebut, kuantitas pelaksanaan kinerja menjadi kurang efektif

Adapun peran Akademisi dan atau generasi muda dalam memerangi narkoba yang sudah sangat Masif di Desa Bandar Baru tersebut adalah sebagai berikut: a) Membentengi diri untuk tidak menyalah gunakan narkoba, apalagi sebagai pengedar narkoba, b) Mempengaruhi teman-temannya baik yang disekolah maupun diluar sekolah untuk tidak terlibat narkoba, c) Bila ada teman-temannya atau keluarganya atau siapa saja yang terlibat sebagai pengguna/pecandu narkoba agar di laporkan kepada BNN Kabupaten Sumbawa atau diantar untuk diobati/diterapi rehabilitasi; d) Memberikan sosialisasi kepada teman-teman di sekolah/di kampus atau dimana saja berada tentang bahaya narkoba terutama di kalangan keluarga kepada adik-adiknya atau kepada kakakkakaknya.

Semua kegiatan-kegiatan tersebut di atas sudah diatur dalam UU No. 35 tahun 2009 tenatang narkotika. Bila tidak dilaksanakan terutama tidak melapor apabila ada salah satu keluarganya sebagai pecandu narkoba atau sengaja tidak melapor padahal mengetahui adanya tindak pidana narkotika maka bisa dikenakan sanksi pidana kurungan dan pidana denda.

\section{SIMPULAN}

Pencegahan, penanggulangan penyalahgunaan, dan peredaran gelap narkoba merupakan tanggung jawab bersama guna mewujudkan kamtibmas yang aman dan kondusif. Harapannya, dapat terwujud stabilitas pembangunan nasional, masyarakat adil, makmur, dan sejahtera Banyak upaya pemulihan namun keberhasilannya sendiri sangat bergantung pada sikap profesionalisme lembaga yang menangani program rehabilitasi ini, 
kesadaran dan kesungguhan penderita untuk sembuh serta dukungan kerja sama antara penderita, keluarga dan lembaga. Masalah yang paling sering timbul dan sulit sekali untuk dihilangkan adalah mencegah datangnya kembali kambuh (relaps) setelah penderita menjalani pengobatan. Relaps ini disebabkan oleh keinginan kuat

\section{DAFTAR PUSTAKA}

Badan Narkotika Nasional, (2007). Pencegahan Penyalahgunaan Narkoba Sejak Usia Dini, Direktorat Deseminasi Informasi, Deputi Pencegahan Badan Narkotika Nasional Republik Indonesia,

Badan Narkotika Nasional, (2017). Narkoba dan Permasalahannya, Jakarta, 2017,

Falah Kharisma, (2014). "NarkobaPembunuhKarakterBangsa" Sumber: http://falah- kharisma. blogspot.co.id/2014/09/bahaya-penyalahgunaan-narkoba.html, diakses pada tanggal 18 Januari 2020, Pukul 17.15 Wib.

Gosita, A. (1993). Masalah Korban Kejahatan, Akademika Pressindo, Jakarta, 1993

Hawari, H. (2002). Konsep Agama Menanggulani NAZA,Dana Bakti Prima, Yogyakarta, 2002

https://regional.kompas.com/read/2019/05/21/17140411/bnn-sebut-256000- warga-sumaterautara-terpapar-narkoba?page=all.Diakses pada tanggal 15 Januari 2020, Pukul 15.00 Wib.

Husein, S. (2003), Kejahatandalam Masyarakat dan Upaya Penanggulangannya, http,//www.digitized.com.

Hutagaol, R. (2019). Perbandingan Kedudukan Penyidik Tindak Pidana Narkotika Menurut Undang-Undang Nomor 35 Tahun 2009 Tentang Narkotika Dan Kitab Undang-Undang Hukum Pidana, Jurnal Ilmiah Penegakan Hukum, 6 (2): 86 - 95

Kharisma, F. (2014). "Narkoba Pembunuh Karakter Bangsa" Sumber: http://falahkharisma.blogspot.co.id/2014/09/bahaya-penyalahgunaan-narkoba.html, diakses pada tanggal 18 Januari 2020, Pukul 17.15 Wib.

Koentjaraningrat. (1976). Metode-metode Penelitian Masyarakat. Jakarta, Penerbit PT Gramedia.

Komari, M. (2000). “Penyalahgunaan Narkoba dan Sanksinya”. Kepolisian Negara Republik Indonesia Daerah Jawa Tengah Resort Cilacap.

Martono, L.H. dan Joewana, S. (2006) Membantu Pemulihan Pecandu Narkoba Dan Keluarganya, Balai Pustaka, Jakarta,

Nadeak, W. (1996), Korban dan Masalah Narkotika, Cetakan IV, Bandung, Indonesia Publishing House.

Nainggolan, M., Elvi Z., dan Saparuddin, (2010), Peranan Hakim dalam Memberikan Perlindungan Hukum terhadap Anak Korban Penyalahgunaan Narkotika (Studi Pengadilan Negeri Lubuk Pakam), Mercatoria, 3 (2): 116-132

Nitibaskara, Ronny. (2001), Organized Crime, http,//www.fortunecity.com.

Sasangka, H. (2003). Narkoba dan Psikotropika Dalam Hukum Pidana. Bandung,

Silalahi, D.H. (2018). Penanggulangan Tindak Pidana Penyalahgunaan Narkotika di SAT RES Narkoba Polres Tebing Tinggi, Jurnal Ilmiah Penegakan Hukum5, (2): 60- 67.

Sirait, E.W. \& Rafiqi (2018). Pertimbangan Hakim dalam Menjatuhkan Putusan Tindak Pidana Narkotika Yang Dilakukan Pengedar pada Putusan No : 2071/Pid.Sus/2016/Pn-Mdn), 5 (1) 2018: 1-7.

Soekanto, S. (2003), Pokok-Pokok Sosiologi Hukum, Grafindo Persada, Jakarta,

Sunyoto, A. (2013). Mencermati Faktor Non Military Security Bahaya Narkoba dan Kejahatan Terorganisasi. Dalam Jurnal Departemen Pertahanan TAPAL BATAS Edisi 17/April 201318 Lihat Erfan Priyambodo, Artikel berjudul Narkoba Di Tinjau Dari Berbagai Agama di Indonesia

Utami, M.P. (2016). Tinjauan Yuridis Terhadap Penyalahgunaan Narkotika, Skripsi, Fakultas Hukum Universitas Hasanuddin, Makassar,

\section{Undang-Undang}

Undang-Undang Nomor 14 Tahun 2005 Tentang Guru Dan Dosen

Undang-Undang Republik Indonesia Nomor 35 Tahun 2009 tentang Narkotika

Undang-Undang Republik Indonesia Nomor 5 Tahun 1997 tentang Psikotropikaa.

h种: //mahesainstitute.web.id/ojs2/index.php/jehss 